Article

\title{
Environmental Impact Assessment (EIA) Using Geographical Information System (GIS): An Integrated Land Suitability Analysis of Filling Stations
}

\author{
Nadiatul Nazleen Ajman ${ }^{1}$, Noor Yasmin Zainun ${ }^{2, *}$, Noralfishah Sulaiman ${ }^{1}$, Shabir Hussain Khahro ${ }^{3, *} \mathbb{}$, \\ Farid Ezanee Mohamed Ghazali ${ }^{4}$ and Mohd Hilton Ahmad ${ }^{2}$ \\ 1 Faculty of Technology Management and Business, Universiti Tun Hussein Onn Malaysia (UTHM), \\ Parit Raja 86400, Malaysia; nadiatulnazleenajman@gmail.com (N.N.A.); nora@uthm.edu.my (N.S.) \\ 2 Faculty of Civil Engineering and Built Environment, Universiti Tun Hussein Onn Malaysia (UTHM), \\ Parit Raja 86400, Malaysia; hilton@uthm.edu.my \\ 3 Department of Engineering Management, Prince Sultan University, Riyadh 11586, Saudi Arabia \\ 4 School of Civil Engineering, Engineering Campus, Universiti Sains Malaysia, Nibong Tebal 14300, Malaysia; \\ cefarid@usm.my \\ * Correspondence: nryasmin@uthm.edu.my (N.Y.Z.); shkhahro@psu.edu.sa (S.H.K.)
}

check for

updates

Citation: Ajman, N.N.; Zainun, N.Y.; Sulaiman, N.; Khahro, S.H.; Ghazali, F.E.M.; Ahmad, M.H. Environmental Impact Assessment (EIA) Using Geographical Information System (GIS): An Integrated Land Suitability Analysis of Filling Stations. Sustainability 2021, 13, 9859. https:// doi.org/10.3390/su13179859

Academic Editor: Peter Burgherr

Received: 30 June 2021

Accepted: 26 August 2021

Published: 2 September 2021

Publisher's Note: MDPI stays neutral with regard to jurisdictional claims in published maps and institutional affiliations.

Copyright: (c) 2021 by the authors. Licensee MDPI, Basel, Switzerland. This article is an open access article distributed under the terms and conditions of the Creative Commons Attribution (CC BY) license (https:// creativecommons.org/licenses/by/ $4.0 /)$.

\begin{abstract}
A stable methodology for conserving the natural environment has been a concern for developing countries. The fast-paced growth of urbanization generated significant demand for automobiles, leading to greater utilization of fuel. The consumption of fuel is fulfilled by the Filling Station (FS). An FS is undoubtedly an important facility, but it is reported that it has high potential for degradation of natural resources, pollution problems, environmental degradation, and hydrological, geological, and socio-economic hazards, and therefore the site selection of such facilities is an essential problem. The traditional approach utilizes EIA assessments and GIS separately and existing models lacks integration. Thus, this study provides an integrated GIS-based land suitability modeling using EIA assessments, and the Analytic Hierarchy Process (AHP) has been used as key land use feature prioritization for the appropriate selection of FS locations. A case study is also carried out to assess the precision of the suggested model. The findings indicate that more than $73 \%$ of the present FS are in the acceptable region, while $27 \%$ of the FS are not in the adequate region using the local code. Furthermore, $58 \%$ of the present FS are in the acceptable region, while $42 \%$ of current FS are not in the adequate region using the international code. The findings of the comparative code analysis show a difference in the codes. The international code looks safer compared to the local code because it has higher buffer distances. This model will assist decision-makers in making better decisions for such land suitability problems for filling stations, and this model can also be extended to other facilities by some modifications in the filters and data layers of the model.
\end{abstract}

Keywords: geographical information system; land use; filling station; environmental impact assessment; analytical hierarchy process

\section{Introduction}

There is a key concern that construction activities are likely to bring significant environmental damage. Developmental projects such as rail projects [1,2], bus stations, petrol pumps [3], wind-solar site selection [4], and infrastructure facilities [5] have high potential to cause harm to the natural environment, including soil degradation, pollution of the atmosphere, and water pollution [6]. The major problem developers are facing today is to develop and implement an approach for sustainable construction activities and to ensure that such activities are environmentally friendly and sustainable [7-9].

The continuous growth in urbanization offers a reasonable demand for cars, causing higher fuel consumption [10] and higher demand of filling stations. This rising demand for fuel is fulfilled by filling stations and electric charging stations for future cars. It is reported 
that an FS has a high potential to impact the site and the surrounding area. It also impacts socio-economic losses, environmental degradation, geological disintegration, and hydrological contamination [11-13]. Fire risk due to open flames is one of the critical hazards of an FS, including several other factors like electricity [10] and pipe and underground storage tank leakage leading to groundwater contamination [14]. Moreover, it also leads to air pollution by aromatic compound concentrations [15] and traffic jams [10]. The FS facility is essential but hazardous. Thus, special attention is needed during the selection of such a facility. Site selection is a key element in any business project [16,17]. Several incidents have already been reported in news whereby a fire occurred at gas stations and filling stations and fatalities occurred. It causes a diverse effect on this industry and the mental distress of users. A few examples are shown in Figure 1.
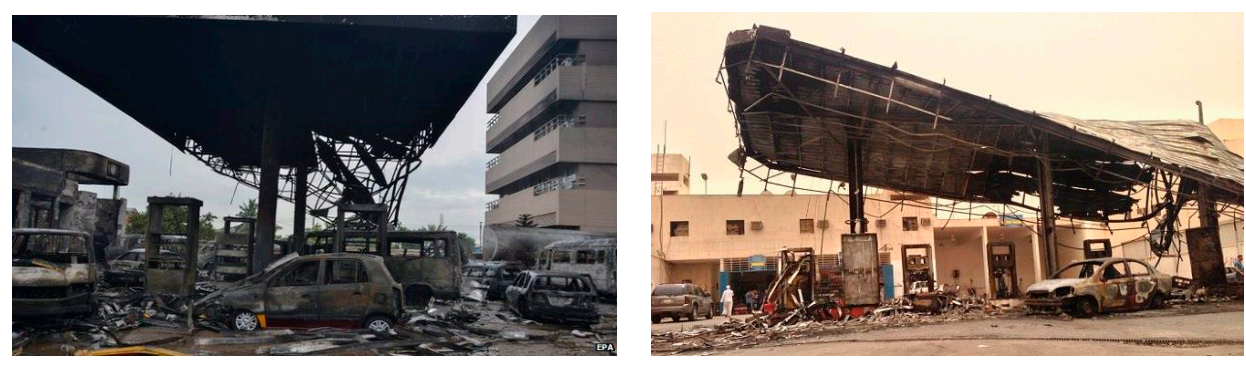

Figure 1. Fire incidents at filling stations [18,19].

It is reported that around 150 people died in a fire at a petrol station in Ghana's capital [18]. A similar incident happened in Jamaica when a petrol station went up in flames, causing injuries to at least seven people [19]. Furthermore, two people were killed and four adults were injured in an explosion at a gas station in Buena Vista, Virginia [20].

EIA has been initiated to put forward a well-designed mechanism that provides structure for collecting, recording information, and providing views on the environmental effects of any new large infrastructure facility [21,22]. EIA is also known as an essential planning and management method assisting the environmental and socio-economic ease of the current urban projects and assesses the suitability of their sites [8,21-23]. EIA analyzes and evaluates planned actions to ensure that the proposed new activity is environmentally sound and sustainable. On the contrary, EIA studies for the land selection process have been seen to be a time- and cost-consuming task [24].

However, while selecting a suitable site, the previous model's onsite suitability is not entirely helpful in meeting the land suitability analysis needs. None of the models integrate EIA with GIS-based suitability modeling for an FS. This problem requires decisionmakers to use a practical and effective method for assessing land suitability. To solve such spatial problems, GIS has been successfully used as a tool to assist decision-makers in the land suitability of the various activities [25-29]. Various factors contribute to selecting an appropriate location for an FS in EIA study in countries where EIA is a prerequisite for approval. Thus, this study integrates EIA requirements in a GIS-based model for suitable site selection.

\section{Literature Review}

A sustainable methodology to protect the natural environment continues to be a subject of interest for researchers. There has been a continual concern for the construction field activities that can damage the environment. The structure of such sites can bring massive damage to natural environment. An FS increases convenience for the transporters and travelers; however, these stations are usually hazardous [14,30]. Site selection is also reported as a key aspect of success for initiating any business facility [31]. This industry has become more concerned with the significant environmental problems and adverse outcomes on the environment globally. Petroleum retail companies are trying to incorporate sound and effective policies for environmental management of an FS as shown in Figure 2. 
For this purpose, the EIA was introduced as an effective tool for better management of such facilities [32].

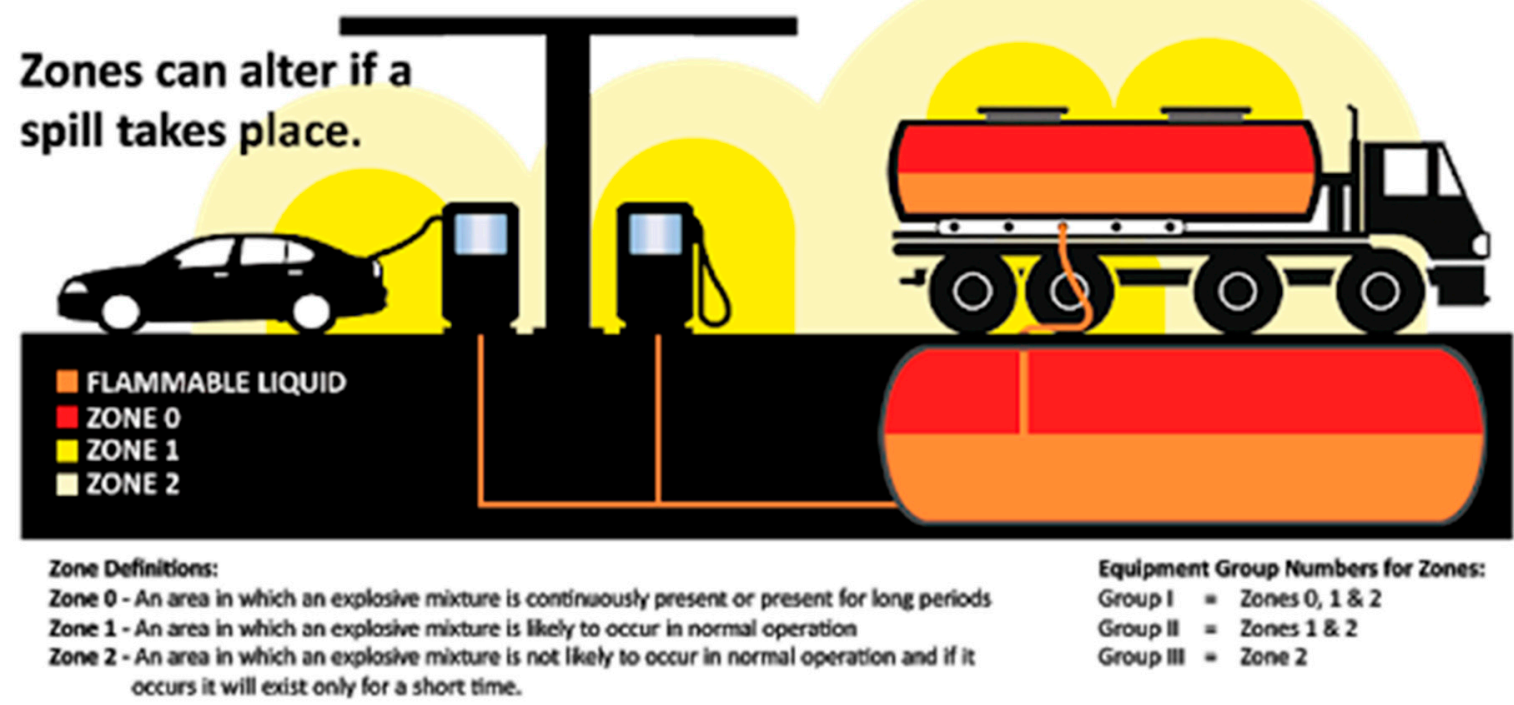

Figure 2. Hazardous zones of possible fire effects on FS [33].

The FS location depends on traffic volume counts by utilizing regression and GIS [34]. Site potentiality is pivotal for business development, as it depends on the number of customers that visit per day. A study was conducted by [35] in the Kano Metropolitan Area in northern Nigeria to assure the concern of entrepreneurs in the field of petrol retailing for considering physical planning standards. It was found that eight (8) stations (4\%) out of 192 stations neglected the criteria set for planned construction [30].

It is argued that construction teams for petrol-filling stations prefer to decide the location based on personally decisive factors; however, for optimal safety of the environment and other preventive measures, there must be a standardized system for doing so. Moreover, it is also observed that before the attainment of permission for the petrol site, one is required to carry out an EIA study [36-39].

EIA encompasses all the necessary examination and analyzes the environmental viability of any project. The steps and procedures involved in carrying out EIA reports require a sufficient amount of effort, time, and cost [40,41]. The former site-selection methods consider qualitative and quantitative criteria for selecting a location. These studies lack factors considered in EIA assessment because several factors are still involved in the EIA examination of any facility such as an FS. An FS is a considerable liability to the environment as they are potentially hazardous to environmental well-being [41]. Therefore, a site investigation and general risk assessment need to be performed to construct such facilities [42].

GIS was introduced in the early stage of this century to solve such land suitability issues. Land suitability involves multi-criterions for any facility. Thus, various Multi Criteria Decision Making (MCDM) approaches are used with GIS in numerous land suitability assessments successfully $[3,6,28,43-46]$. GIS and the AHP approach have been used for sufficient projects successfully, including wind sites [4], infrastructure services [5], housing sites [25], setting water storage reservoirs [47], deciding on sites for nuclear waste disposal [26], land suitability selection of landfill sites [48], sustainable rice production [49], urban growth prediction [50], and the selection of waste disposal sites [51], and land suitability for petrol filling stations [52]. Based on the fitness, ease, and success of the AHP, this research also uses AHP as an MCDM approach to prioritize the dataset layers. 


\section{Research Methodology}

This research is carried out in three phases. Each phase has various processes as shown in Figure 3.

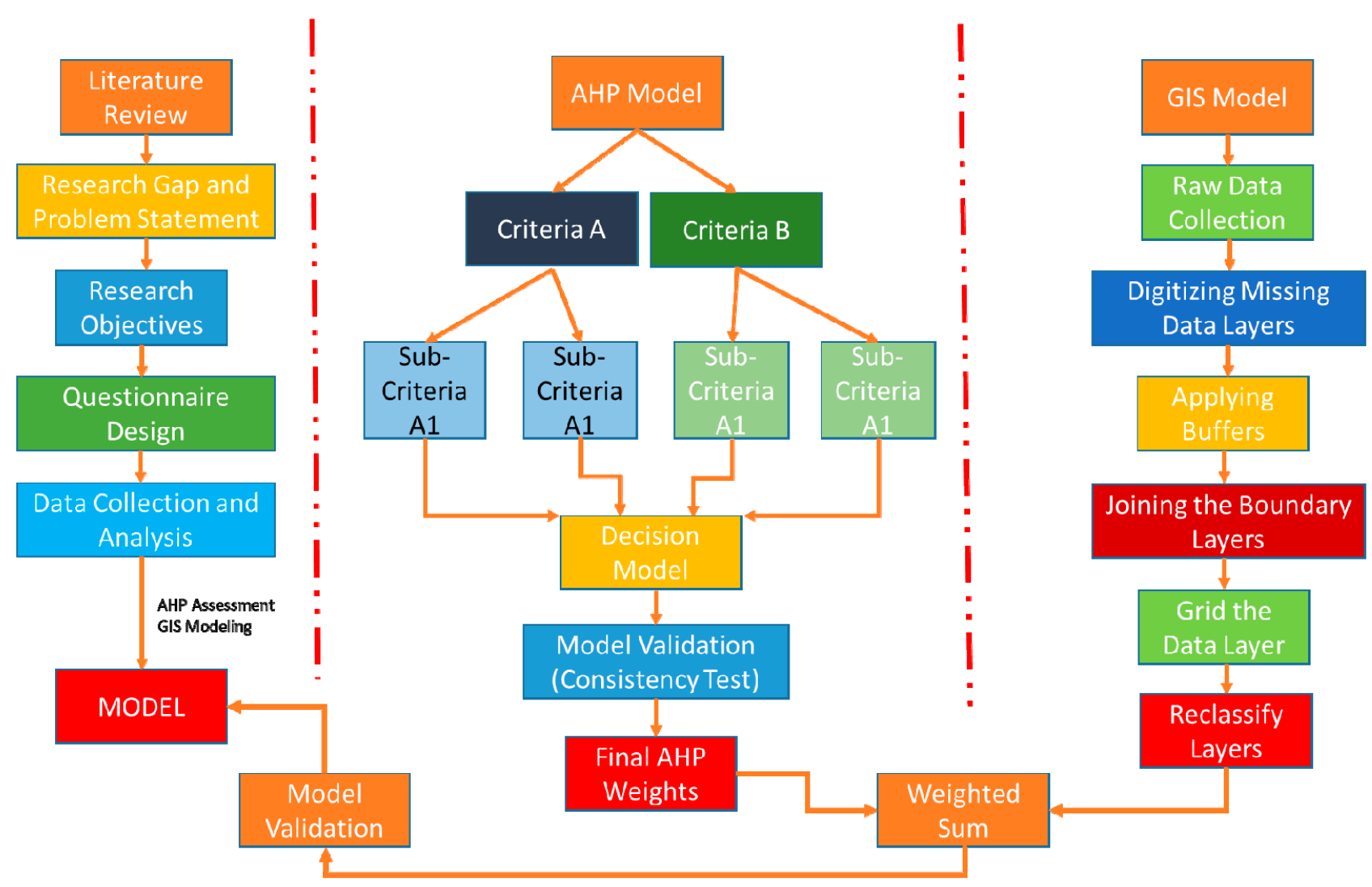

Figure 3. Research flow of the complete research.

The first phase is the general workflow of the research, including the problem query generation. It refines the query into a research problem followed by the study's objective and other steps as shown in Figure 3. In the second phase, the whole decision-making approach shows the AHP process and how the final weights are driven from the data. The AHP weights are validated using the sensitivity test in Expert Choice, and possible deviation in the decision was analyzed. A questionnaire was created to obtain the experts input and questions were placed in a pairwise comparison manner as per the AHP theorem using the AHP 1-to-9-point scale. The questionnaires were sent to experts and details are given in the following sections. The collected data were analyzed with the Expert Choice tool, and a final list of weights was generated. The results were also validated using a sensitivity test, and a final list of the different data layers priority is shown in Appendix A.

The GIS modeling process is shown in the third phase, including all the data collection processes and their preparation for the GIS environment. It is also shown that the safe distances are applied as per the suggested code selected in this study, and the data layers were prepared accordingly for this study. After the buffer application, the data layers were joined, and georeferencing was done in the tool. The data layers were overlaid on each other using the overlay command with AHP weights. Once the GIS maps were generated, the map validation was done using the hand GPS, obtaining the locations of the existing FS in the area to check the precision of the model. 


\subsection{Data Collection}

The raw maps are collected from Malaysia's local city management department that deals with Mapping and Surveying. The data were collected for the city of Ipoh as it was nearest large city and model validation was also convenient. The maps were collected in $(\mathrm{dwg})$ drawing format. The data are consistent with several data layers, including land use maps, topographical details, hydrological details, and natural resources. The scale of the information is 1:25,000 and encompasses 450 square kilometers of area. The reason for choosing this scale is the data availability as GIS images are not easy to collect. So, the selected scale was only available for GIS images.

\subsection{Questionnaire Design, Distribution and Collection}

A detailed literature review has been carried out to identify the key factors that the EIA study extracted from the literature. Various EIA reports were also reviewed to identify the selection features, which are part of the EIA assessment (Appendix B), and its suitability for suitable land parcel selection for FS [53-57]. A questionnaire was designed to attain the stakeholder's opinion regarding the suitability of data filters to properly select land parcels for filling stations. The forms were forwarded to various environmental experts via email and hard copy. An estimated 160 questionnaires were sent, and in the end, 132 were collected successfully. After careful evaluation of the questionnaires, two were ignored due to inappropriate data. Finally, 130 were selected and analyzed by the expert choice tool for the final dataset of the land-use layers.

\subsection{Criteria Combined List of the Spatial Data Buffering}

There are numerous land-use layers involved in any decision-making process of suitable land parcel selection. The data layers are categorized into two main classes, including Criteria and Sub-criteria. Each data layer has some safe buffer zone from the location of an FS. Each country has different buffer zone values for all facilities including the FS, and the suitable land parcel is selected accordingly. Ipoh was selected due to the case study area, whereas Jamaica was selected due to high buffer distances. The suggested buffer values for selecting the suitable land parcel of FS for this case study are shown in Table 1.

Table 1. Criteria combined list of the spatial data buffering with values.

\begin{tabular}{|c|c|c|c|c|}
\hline S.No & Criteria & Sub Criteria & Ipoh & Jamaica \\
\hline 1 & \multirow{8}{*}{ Land Use Protection } & Residential Zone & \multirow{8}{*}{20 feet } & 100 feet \\
\hline 2 & & Educational Zone & & 500 feet \\
\hline 3 & & Health Care Zone & & 500 feet \\
\hline 4 & & Commercial Zone & & 100 feet \\
\hline 5 & & Industrial One & & 100 feet \\
\hline 6 & & Religious Zone & & 500 feet \\
\hline 7 & & Historic Zone & & 500 feet \\
\hline 8 & & Parks \& Play Grounds & & 500 feet \\
\hline 9 & \multirow{5}{*}{ Accessibility } & Dual Highway & \multirow{5}{*}{20 feet } & 100 feet \\
\hline 10 & & Primary Roads & & 40 feet \\
\hline 11 & & Secondary Roads & & 40 feet \\
\hline 12 & & Railway Line & & 820 feet \\
\hline 13 & & Airport & & 4920 feet \\
\hline 14 & \multirow{2}{*}{$\begin{array}{l}\text { Hydrological } \\
\text { Conditions }\end{array}$} & Rivers & \multirow{2}{*}{20 feet } & 500 feet \\
\hline 15 & & Lakes & & 300 feet \\
\hline
\end{tabular}


Table 1. Cont

\begin{tabular}{|c|c|c|c|c|}
\hline S.No & Criteria & Sub Criteria & Ipoh & Jamaica \\
\hline 16 & \multirow{2}{*}{ Natural Environment } & Vacant Land & \multicolumn{2}{|c|}{ Preferable Land } \\
\hline 17 & & Forest & 20 feet & 3280 feet \\
\hline 18 & Topography & Slope & $<30 \%$ & $<35 \%$ \\
\hline 19 & \multirow{2}{*}{ Utility Services } & $\begin{array}{c}\text { High Voltage } \\
\text { Transmission Line }\end{array}$ & \multirow{2}{*}{20 feet } & 150 feet \\
\hline 20 & & Water Pipes & & 100 feet \\
\hline
\end{tabular}

The local city code was used in this case study and collected from the local municipal community of the town. A comparative assessment was also done in the study to compare the results with international codes. The structural design of the AHP model used in the research can be observed in Figure 4.
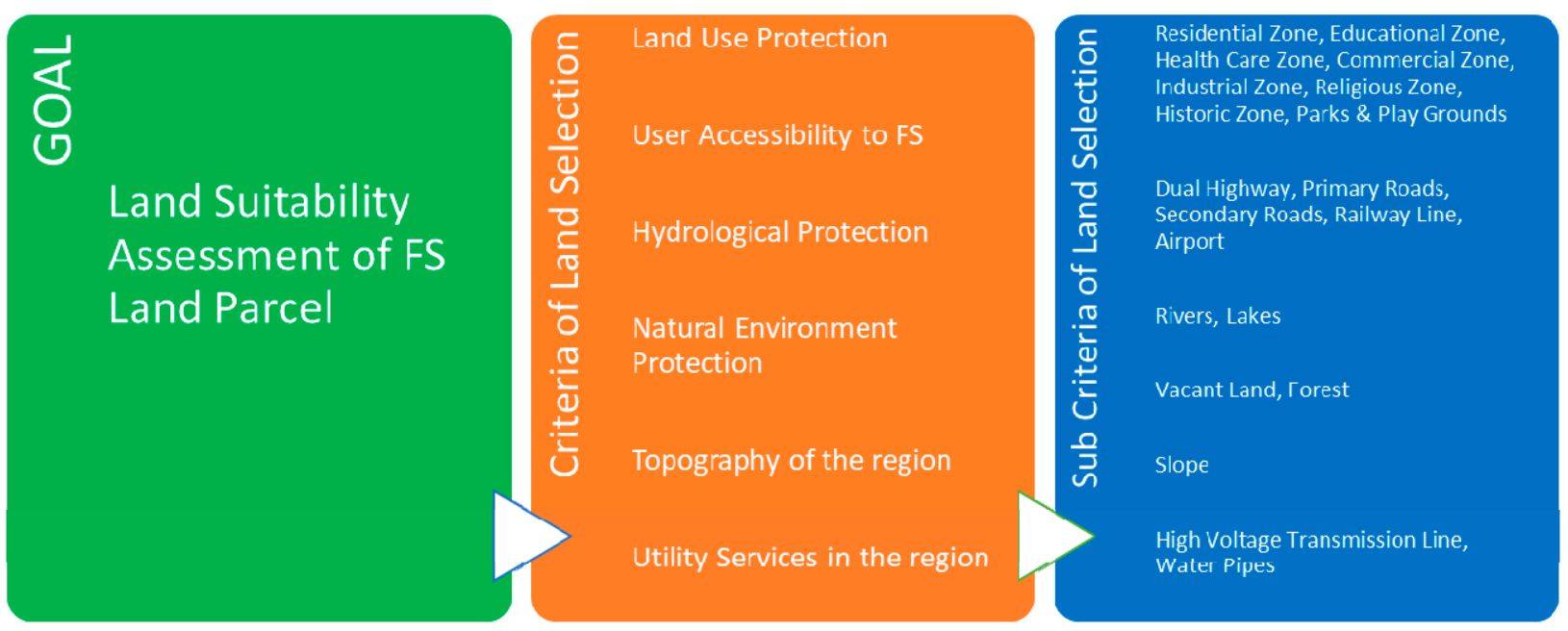

Figure 4. AHP decision-making model.

All criteria and sub-criteria are significant, but each layer has superiority over the other based on the nature of the development activities. Therefore, this AHP model assisted in prioritizing the criterion level and sub-criteria for this study after obtaining the expert's feedback using the AHP questionnaire designed for this study. The final weights after expert feedback are shown in Appendix A.

\subsection{Validation of the Model}

The model's validity was elaborated throughout the model. The factors selected were validated by accumulating information by interviewing EIA consultants and experts of the environmental sciences from governmental and non-governmental firms. The participants' opinions and views were considered, and the list of the factors was added to the questionnaire. As discussed earlier, the forms were forwarded to the stakeholders that deal with land selection for the new filling station to obtain their opinion. The stakeholders' input was analyzed in the Expert Choice statistical package, and the consistency ratio index investigated the inconsistency in the final decisions.

The final weights of the selection criteria for land suitability were validated by using a sensitivity test. The examination was carried out at intervals of different percentages, and all noteworthy changes were considered accordingly.

The second-tier validation was done using hand GPS, and the land suitability map for filling stations was validated by overlaying the existing filling stations in the study area. The existing filling stations were officially approved by the department of environment, 
Malaysia. If there was a significant difference, then we had to revise the decision. Thus, the EIA-based GIS integration method proposed by this study for land suitability evaluation will be a tool to help planners and decision-makers to make complex spatial decisions of filling stations.

\section{Results and Discussion}

At the last stage, all the data layers are prepared to get the final land suitability map. This is done by combining the complete data layers using the sum command of ArcGIS. Figure 5 shows the map for land suitability of the possible new filling stations using the code suggested by the National Environmental Dental Protection Agency (NEPA), Kingston, Jamaica.

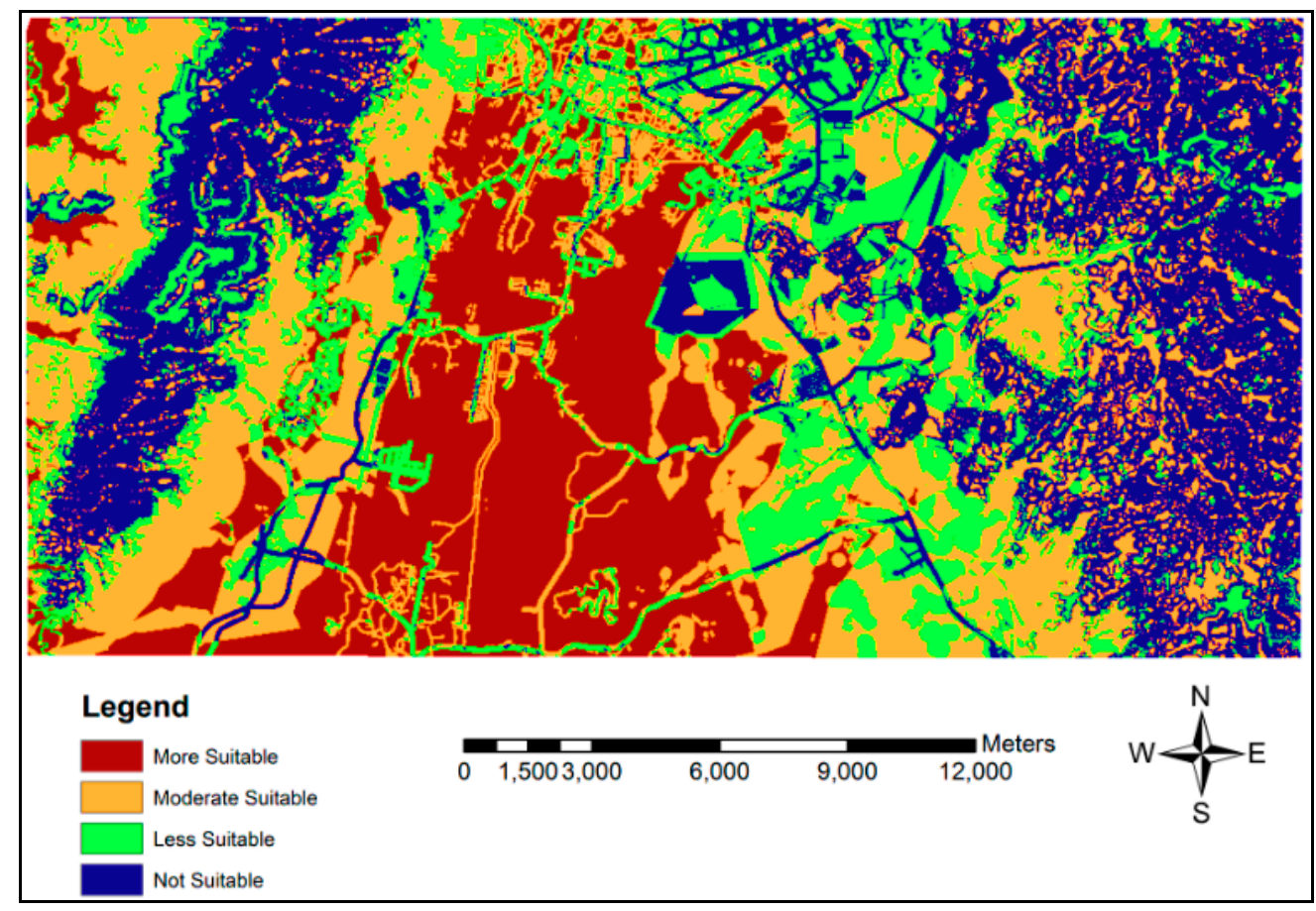

Figure 5. Final land suitability map for FS rendering to NEPA Code.

The brown color shows the most suitable zone for installing new filling station as it met the most required conditions of different data layers. The orange color is the moderately suitable zone for installing new filling station as it met the data layer requirements to a good extent. The light green color shows the zone with less suitability and blue represents the unsuitable zone for installing new filling stations, because both violate the basic requirements of different data layers. Similarly, Figure 6 portrays the completed land suitability criteria for the initial filling station in accordance with the code suggested by the City Planning Department (CPD), Ipoh, Malaysia.

The dark green color shows the most suitable zone for installing a new filling station as it met the most required conditions of different data layers. The pink color is the moderately suitable zone for installing a new filling station as it met the data layer requirements to a good extent. The red color shows the zone with less suitability and blue shows the unsuitable zone for installing a new filling station because both violate the basic requirements of different data layers.

The overlaying technique was adopted for validating the aforementioned new land suitability chart for FS. It could be recognized that the data layer of the current FS was established from their coordinates. The coordinates were collected from the Malaysian Geospatial Data Infrastructure (MyGDI) course available online. These coordinates were manually analyzed using the Global Positioning System (GPS). Using Garmin hand GPSMAP76CX, 
the coordinates of various random existing FS were obtained. This is done to test the validity of MyGDI gathered data. Therefore, as shown in Figure 7, the current FS map is superimposed with the land suitability map using the international code, which is NEPA.

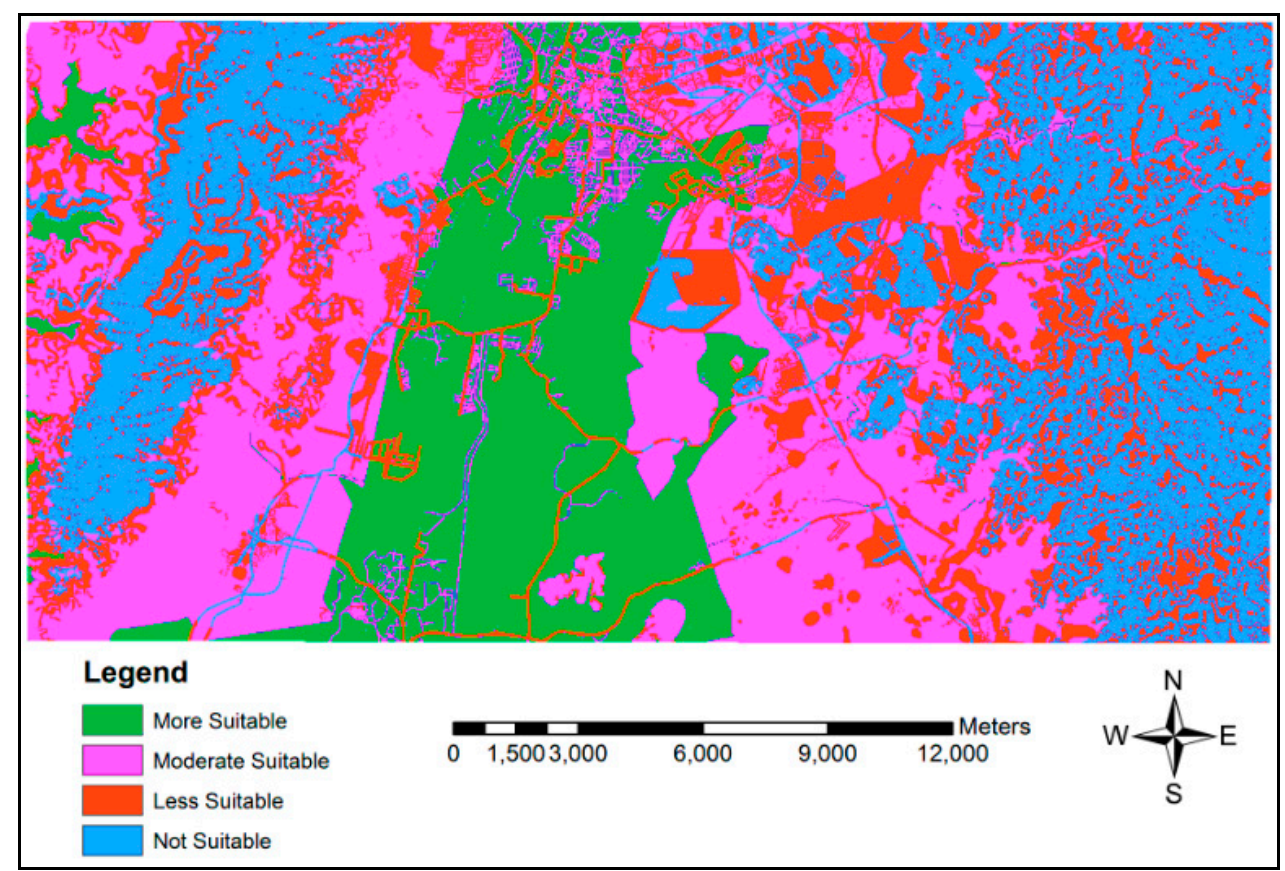

Figure 6. Final land suitability map for FS rendering to CPD Code.

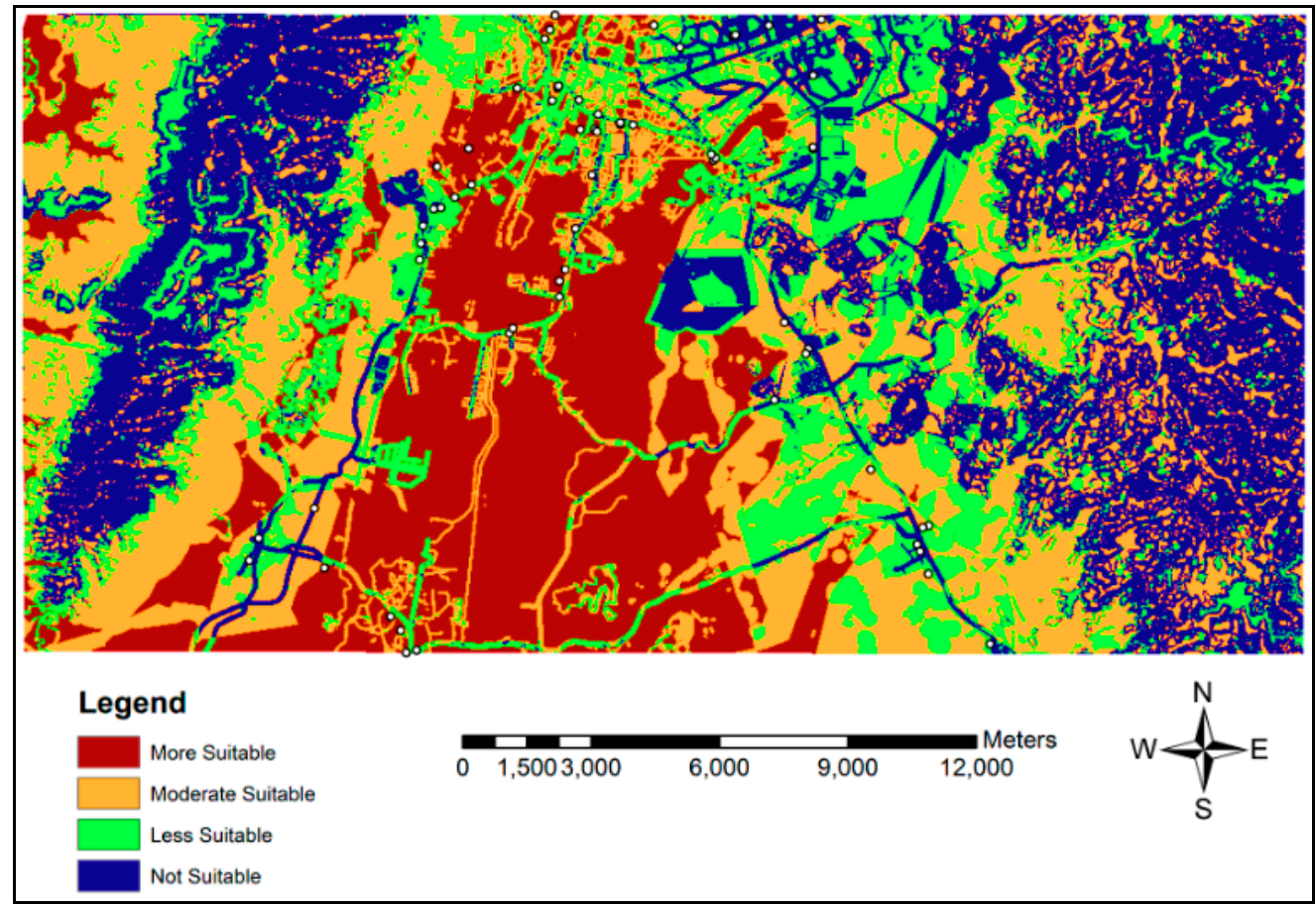

Figure 7. Land suitability map rendering to NEPA Code with existing FS.

Similarly, as shown in Figure 8, the current FS map is superimposed with the latest land suitability map using the local code. 


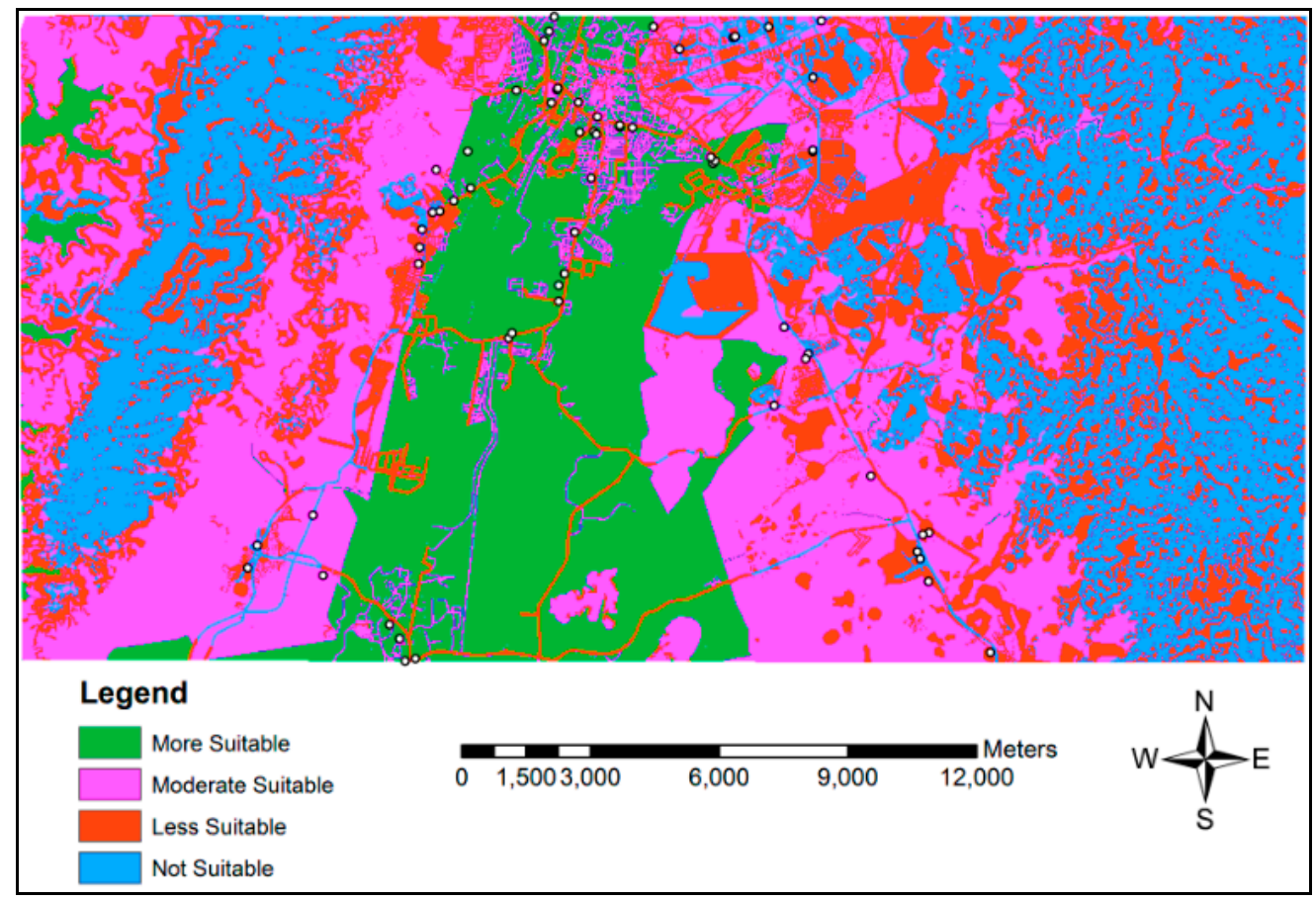

Figure 8. Land suitability map rendering to CPD Code with existing FS.

There were 64 existing FS in the study area, and their locations can be analyzed graphically from the above figures. Table 2 shows the suitability index's overall results generated using this EIA-based GIS approach for land suitability of FS using both codes.

Table 2. Results of suitability index.

\begin{tabular}{ccccc}
\hline S.No & $\begin{array}{c}\text { Suitability } \\
\text { Index }\end{array}$ & $\begin{array}{c}\text { No: of FS } \\
\text { (Local) }\end{array}$ & $\begin{array}{c}\text { No: of FS } \\
\text { (NEPA) }\end{array}$ & Deviation \\
\hline $\mathbf{1}$ & Most Suitable & 28 & 16 & 12 \\
\hline $\mathbf{2}$ & $\begin{array}{c}\text { Moderate } \\
\text { Suitable }\end{array}$ & 19 & 21 & 2 \\
\hline $\mathbf{3}$ & Less Suitable & 12 & 16 & 4 \\
\hline $\mathbf{4}$ & Not Suitable & 5 & 11 & 6 \\
\hline & Total No: of PFS & 64 & 64 & \\
\hline
\end{tabular}

It was analyzed that 28 existing FS are in the most suitable zone followed by 19 FS in the moderately suitable zone, $12 \mathrm{FS}$ in the less suitable zone, and 5 FS in the not suitable zone, using the local city code. The local code is fine, but there is still FS is in the less suitable and not suitable zone, whereas 16 existing FS are in the most suitable zone followed by 21 FS in the moderately suitable zone, 16 FS in the less suitable zone, and 11 FS in the unsuitable zone using the international code. There is an almost $22 \%$ deviation in the location of FS in the most suitable and moderately suitable zone in both codes. At the same time, the deviation is almost $15 \%$ in the less suitable and not suitable zone in both codes. The results show that the city government is conducting good practice locating the FS, but there is still a gap to improve this land suitability practice.

\section{Conclusions}

There is a rising issue related to the construction development processes, expected to cause significant environmental harm. Projects such as railways, bus stations, petrol stations, windmills, factories, and services have a higher potential for environmental degradation. The main challenge for developers today is to design processes and impose procedures for the sustainable development of construction projects. EIA is integrated in this study to present an effective structured system that provides a basis for the ac- 
cumulation of information and presents views on the environmental consequences of the new business locations. EIA is majorly used for the pivotal planning and ensuring environmental safety considering the consequential harms of urban construction projects. Hence, it should not be overlooked, and such an important facility should be carefully selected using GIS models with any code for safe distances. This issue requires attention due to its potential to harm the environment. Any FS and other facilities site should be carefully selected with proper buffer distances to protect the environment, property, and humans. Facilities that are potentially hazardous should be located at a certain distance using promising site selection approaches because a small piece of error or negligence may harm natural resources, environment, business, and humans.

It is analyzed that almost $73 \%$ of the present FS are in the acceptable region, while still, $27 \%$ of the total current FS are in the less suitable and non-suitable zones as per the local city code. Meanwhile, the international code used in this study as a comparative assessment appears to be safer due to its higher buffer distances. It is observed that $58 \%$ of the present FS are in the acceptable zone, but $42 \%$ of the total current FS are still in the less suitable and non-suitable zones as per the international code. It is analyzed that there is still a significant number of FS located in the less suitable and non-suitable zones of the city using both codes.

Based on the results, it is encouraged to use the proposed land suitability model for such issues; this new EIA-based GIS model for land suitability can be helpful for other facilities too. The model can also be used for other facilities with some safety distances and data layers modifications.

Every model has certain fitness and acceptability. Similarly, this model is limited to FS site selection only. The model has key factors that are primarily considered in FS site selection. The model can be modified for other site selection facilities with some modifications in the factor list and buffer distances. The model can be used in plane terrain and even in mountainous terrain. The model has been assessed at a $50 \mathrm{KM}$ maximum distance, but a lower study area can give better results and accuracy.

Author Contributions: Write up and analysis N.N.A., Supervision and Support N.Y.Z., Data collection N.S., Concept, write up and review S.H.K., Facility Support F.E.M.G. and Proof read M.H.A. All authors have read and agreed to the published version of the manuscript.

Funding: This research work is supported by the KANZU Knowledge Consultant, under Ibn Battuta grant, VOT (M014)". This work is also supported by Universiti Sains Malaysia-Research University Individual (RUI) [Grant number 1001.PAWAM.8014153].

Institutional Review Board Statement: Not applicable.

Informed Consent Statement: Not applicable.

Data Availability Statement: The data can be accessed on request from corresponding authors.

Conflicts of Interest: The authors declare that there is no conflict of interest.

\section{Appendix A}

Table A1. Synthesize Factor List.

\begin{tabular}{ccc}
\hline Selection Factor & Synthesize Weight & Data Layer Rank \\
\hline Primary Road & 0.156 & 1 \\
\hline Vacant Land & 0.097 & 2 \\
\hline Secondary Road & 0.087 & 3 \\
\hline Slope & 0.07 & 4 \\
\hline Elevation & 0.059 & 5 \\
\hline River & 0.054 & 6 \\
\hline
\end{tabular}


Table A1. Cont.

\begin{tabular}{ccc}
\hline Selection Factor & Synthesize Weight & Data Layer Rank \\
\hline Highway & 0.052 & 7 \\
\hline Water Pipe Line & 0.051 & 8 \\
\hline Commercial Zone & 0.048 & 9 \\
\hline Industrial Zone & 0.045 & 10 \\
\hline Transmission Line & 0.043 & 11 \\
\hline Lake & 0.037 & 12 \\
\hline Residential Zone & 0.034 & 13 \\
\hline Education Zone & 0.033 & 14 \\
\hline Forest & 0.021 & 15 \\
\hline Health Caring Zone & 0.02 & 16 \\
\hline Religious Zone & 0.02 & 16 \\
\hline Parks and Play Grounds & 0.02 & 16 \\
\hline Rail Line & 0.02 & 16 \\
\hline Historical Buildings & 0.017 & 17 \\
\hline Airport & 0.016 & 18 \\
\hline Total Weight Sum & 1 & \\
\hline
\end{tabular}

\section{Appendix B}

Table A2. EIA Reports.

\begin{tabular}{|c|c|c|c|}
\hline S. No & Report Title & Year & Reference \\
\hline 1 & $\begin{array}{l}\text { Environmental Impact Assessment } \\
\text { Report for an Application for } \\
\text { Exploration Right for Petroleum }\end{array}$ & 2020 & [18] \\
\hline 2 & $\begin{array}{l}\text { Environmental Impact Assessment } \\
\text { for the Establishment and Operation } \\
\text { of a Proposed Fuel Service Station } \\
\text { Project at Omutshona Filling Station, } \\
\text { Okatana, Oshana Region }\end{array}$ & 2020 & [35] \\
\hline 3 & $\begin{array}{l}\text { A Comparative Nexus of Impact } \\
\text { Assessment of Filling Station } \\
\text { Construction Projects on } \\
\text { Environmental Sustainability in } \\
\text { Owerri, Imo State: An Empirical } \\
\text { Perspective }\end{array}$ & 2019 & [43] \\
\hline 4 & $\begin{array}{l}\text { Environmental Impact Assessment } \\
\text { of Petrol and Gas Filling Stations on } \\
\text { Air Quality in Umuahia, Nigeria }\end{array}$ & 2015 & [44] \\
\hline 5 & $\begin{array}{l}\text { Environmental Impact Assessment } \\
\text { Study Report for The Proposed } \\
\text { Maseki Filling Station in Kitui On } \\
\text { Plot L.R. No.899, Kitui County }\end{array}$ & 2014 & [7] \\
\hline 6 & $\begin{array}{c}\text { Environmental Scoping Report (ESR) } \\
\text { For A Fuel Storage Facility }\end{array}$ & 2020 & [58] \\
\hline
\end{tabular}




\section{References}

1. Mshelia, A.M.; John, A.; Emmanuel, D.D. Environmental Effects of Petrol Stations at Close Proximities to Residential Buildings in Maiduguri and Jere, Borno State, Nigeria. IOSR J. Humanit. Soc. Sci. 2015, 20, 1-8.

2. Aguib, A.; Garni, D.A.; Smith, S. Application of Remote Sensing and GIS for Locating Suitable Mangrove Plantation Sites along the Saudi Arabian Red Sea Coast. Available online: http:/ / sfrc.ufl.edu/faculty/ssmith/Sea_Coast.pdf (accessed on 21 January 2013).

3. Ali, Z.; Khan, D.; Hussain, R. Adaptation Measures in EIA and Risks Management: An Overview of the Legal Framework in Pakistan. Online J. Sci. Technol. 2012, 2, 1-11.

4. Anifowose, Y.; Omole, K.; Akingbade, O. Waste Disposal Site Selection Using Remote Sensing and GIS: A Study of Akure and Its Environs, Southwest-Nigeria. COLERM Proc. 2012, 2, 526-533.

5. Appiah, D.O.; Schröder, D.; Forkuo, E.K.; Bugri, J.T. Application of Geo-Information Techniques in Land Use and Land Cover Change Analysis in a Peri-Urban District of Ghana. ISPRS Int. J. Geo-Inf. 2015, 4, 1265-1289. [CrossRef]

6. Carrión, J.A.; Estrella, A.E.; Dols, F.A.; Toro, M.Z.; Rodríguez, M.; Ridao, A.R. Environmental Decision-Support Systems for Evaluating the Carrying Capacity of Land Areas: Optimal Site Selection for Grid-Connected Photovoltaic Power Plants. Renew. Sustain. Energy Rev. 2008, 12, 2358-2380. [CrossRef]

7. Arumaningrum, D.G. Environmental Impact Assessment Study Report for The Proposed Maseki Filling Station in Kitui on Plot, L.R. Lincolin Arsyad 2014, 3. Available online: http://journal.stainkudus.ac.id/index.php/equilibrium/article/view/1268/1127 (accessed on 1 June 2021).

8. Matori, A.N.; Aulia, B.U. Suitability Analysis of Petrol Filling Station Site Using GIS. Malays. Constr. Res. Journal (MCRJ) 2010, 7, $1-14$.

9. Choudhury, E.; Das, E. GIS and Remote Sensing for Landfill Site Selection-A Case Study on Dharmanagar Nagar Panchayet. IOSR J. Environ. Sci. Toxicol. Food Technol. 2012, 1, 36-43. [CrossRef]

10. Darko, S. Ghana Petrol Station Inferno Kills about 150 in Accra-BBC News. Available online: https://www.bbc.com/news/ world-africa-33003673 (accessed on 1 June 2015).

11. Moghaddam, D.D.; Haghizadeh, A.; Tahmasebipour, N.; Zeinivand, H. Introducing the Coupled Stepwise Areal Constraining and Mahalanobis Distance: A Promising MCDM-Based Probabilistic Model for Landfill Site Selection. Environ. Sci. Pollut. Res. 2020, 27, 24954-24966. [CrossRef] [PubMed]

12. De Siqueira, C.B.A.; de Mello, R. A Decision Support Method for Environmental Impact Assessment Using a Fuzzy Logic Approach. Ecol. Econ. 2006, 58, 170-181. [CrossRef]

13. Deeb, R.A.; Hu, H.Y.; Hanson, J.R.; Scow, K.M.; Alvarez-Cohen, L. Substrate Interactions in BTEX and MTBE Mixtures by an MTBE-Degrading Isolate. Environ. Sci. Technol. 2001, 35, 312-317. [CrossRef]

14. Ekanayake, L.L.; Ofori, G. Construction material waste source evaluation. In Proceedings of the Second Southern African Conference on Sustainable Development in the Built Environment, Pretoria, South Africa, 9-11 December 2015; pp. $23-25$.

15. Internationl Finance Corporation (IFC). Environmental, Health, and Safety Guidelines for Cement and Lime Manufacturing; IFC: Washington, DC, USA, 2007.

16. Ghayoumian, J.; Saravi, M.M.; Feiznia, S.; Nouri, B.; Malekian, A. Application of GIS Techniques to Determine Areas Most Suitable for Artificial Groundwater Recharge in a Coastal Aquifer in Southern Iran. J. Asian Earth Sci. 2007, 30, 364-374. [CrossRef]

17. Hassanain, M.A.; Al-Mudhei, A. Fire Safety Evaluation of Motor Fuel Dispensing Facilities. Struct. Surv. 2006, 24, 65-76. [CrossRef]

18. Hemming, M. Environmental Impact Assessment Report for an Application for Exploration Right for Petroleum; Rhino Oil and Gas Exploration South Africa: Cape Town, South Africa, 2020.

19. Hamid, A.B.; Iman, M.H.; Suriatini, B.I.; Martin, R.B.T. Site Potentiality of Petrol Stations Based on Traffic Counts. Malays. J. Real Estate 2009, 4, 10-33.

20. Huang, L.; Sheng, G.; Wang, L. GIS-Based Hierarchy Process for the Suitability Analysis of Nuclear Waste Disposal Site. Environ. Inform. Arch. 2006, 1, 289-296.

21. Huang, Z.; Liu, X. A Hierarchical Approach to Optimizing Bus Stop Distribution in Large and Fast Developing Cities. ISPRS Int. J. Geo-Inf. 2014, 3, 554-564. [CrossRef]

22. Hussain, S.; Nassir, A.; Ahmed, I.; Aftab, M. Land Suitability Analysis for Installing New Petrol Filling Stations Using GIS. Procedia Eng. 2014, 77, 28-36. [CrossRef]

23. Increase Safety and Lower Costs with Accurate Area Classification. Available online: https://www.exveritas.com/service/sitesafety-consultancy /area-classification/ (accessed on 1 June 2021).

24. Islam, M.M.; Ahamed, T.; Noguchi, R. Land Suitability and Insurance Premiums: A GIS-Based Multicriteria Analysis Approach for Sustainable Rice Production. Sustainability 2018, 10, 1759. [CrossRef]

25. Jamaica: Seven Injured in Fiery Explosion at Mandeville Gas Station. Available online: https://www.stabroeknews. com/2020/02/22/news/regional/jamaica/jamaica-seven-injured-in-fiery-explosion-at-mandeville-gas-station/\#: \{\}: text=Jamaica\%3ASeveninjuredinfieryexplosionatMandevillegasstation,-Fireragesat\&text=(JamaicaGleaner)Dramatic (accessed on 1 June 2021).

26. Kazuva, E.; Zhang, J.; Tong, Z.; Liu, X.P.; Memon, S.; Mhache, E. GIS- and MCD-Based Suitability Assessment for Optimized Location of Solid Waste Landfills in Dar Es Salaam, Tanzania. Environ. Sci. Pollut. Res. 2021, 28, 11259-11278. [CrossRef] 
27. Khahro, S.H.; Matori, A.; Chandio, I.A.; Aftab, M.; Talpur, A. EIA-based GIS land suitability modelling using multi criteria decision making approach: A framework. In Proceedings of the IEEE Symposium on Business, Engineering and Industrial Applications, Kuching, Malaysia, 22-25 September 2013.

28. Khahro, S.H.; Matori, A.; Chandio, I.A.; Aftab, M.; Talpur, A. Proposed GIS-based Environmental Impact Assessment approach for site suitability of Petrol. Filling Stations in Malaysia. In Proceedings of the International Conference on Civil, Offshore \& Environmental Engineering, Kuala Lumpur, Malaysia, 12-14 June 2012.

29. Khoso, A.R.; Siddiqui, F.H.; Khahro, S.H.; Akhund, M.A. Entrepreneurship in Construction Industry: Motives and Barriers. Int. J. Civil. Eng. Technol. 2017, 8, 491-499.

30. Kirby, R.S. GIS and Public Health. Ann. Assoc. Am. Geogr. 2003, 93, 261-263. [CrossRef]

31. Koc, A.; Turk, S.; Şahin, G. Multi-Criteria of Wind-Solar Site Selection Problem Using a GIS-AHP-Based Approach with an Application in Igdir Province/Turkey. Environ. Sci. Pollut. Res. 2019, 26, 32298-32310. [CrossRef]

32. Taylor, T.K.; Sichinsambwe, C.; Chansa, B. Public Perceptions on Location of Filling Stations in the City of Kitwe in Zambia. Dev. Ctry. Stud. 2016, 6, 133-151.

33. Lin, Y.; Hoover, J.; Beene, D.; Erdei, E.; Liu, Z. Environmental Risk Mapping of Potential Abandoned Uranium Mine Contamination on the Navajo Nation, USA, Using a GIS-Based Multi-Criteria Decision Analysis Approach. Environ. Sci. Pollut. Res. 2020, 27, 30542-30557. [CrossRef] [PubMed]

34. Malczewski, J. GIS-Based Multicriteria Decision Analysis a Survey of the Literature. Int. J. Geogr. Inf. Sci. 2007, 20, 703-726. [CrossRef]

35. Hangula, L.M.; Shagama, F.N. Environmental Impact Assessment for the Establishment and Operation of a Proposed Fuel Service Station Project at Omutshona Filling Station, Okatana, Oshana Region; Omutshona Filling Station: Okatana, Namibia, 2020.

36. Pedersen, K.; Przychodzka, M.; Civiš, M.; Hinson, A.V. Environmental Impact Assessment of Petrol Usage. In Environmental Studies; Aarhus University: Aarhus, Denmark, 2003.

37. Mohammed, M.U.; Jeb, D.N.; Musa, I.J. GIS-Based Analysis of the Location of Filling Stations in Metropolitan Kano against the Physical Planning Standards. Am. J. Eng. Res. 2014, 3, 147-158. [CrossRef]

38. Mulroy, P. Environmental Site Investigation and Due Diligence in current Market. In Proceedings of the Environmental APEA Petroleum Seminar, Cork, Ireland, 15 November 2012.

39. Mundjulu, I. Environmental Scoping Report (ESR) for a Fuel Storage Facility; Ocean Bunker Petroleum Services: Windhoek, Namibia, 2020.

40. Mwania, L.M.; Kitengela, K. Proposed Construction of a Filling Station On Plot No. Makindu/Kiboko B/687 Makindu. In Environmental Impact Assessment Study Report; Makueni County: Wote, Kenya, 2013.

41. Njoku, C.G.; Alagbe, A.O. Site Suitability Assessment of Petrol Filling Stations (PFSs) in Oyo Town, Oyo State, Nigeria: A Geographic Information Systems (GIS) Approach. IOSR J. Environ. Sci. Toxicol. Food Technol. 2015, 9, 8-19. [CrossRef]

42. O'Faircheallaigh, C. Public Participation and Environmental Impact Assessment: Purposes, Implications, and Lessons for Public Policy Making. Environ. Impact Assess. Rev. 2010, 30, 19-27. [CrossRef]

43. Oguzie, J.O.C.; Njoku, P.P.C.; Onwuka, U.S. A Comparative Nexus of Impact Assessment of Filling Station Construction Projects on Environmental Sustainability in Owerri, Imo State: An Empirical Perspective. Eur. Proj. Manag. J. 2019, 9. [CrossRef]

44. Okonkwo, U.; Orji, I.; Onwuamaeze, I. Environmental Impact Assessment of Petrol and Gas Filling Stations on Air Quality in Umuahia, Nigeria. Glob. J. Eng. Res. 2015, 3, 11-20. [CrossRef]

45. Onyeizugbe, C.U.; Orogbu, O.L.; Onyilofor, T.U.; Ugbomhe, O.U. Business Development and Sustainability of Selected Petrol Stations in Anambra State of Nigeria. Afr. J. Bus. Manag. 2018, 12, 11-20. [CrossRef]

46. Özkan, B.; Özceylan, E.; Sarıçiçek, İ. GIS-Based MCDM Modeling for Landfill Site Suitability Analysis: A Comprehensive Review of the Literature. Environ. Sci. Pollut. Res. 2019, 26, 30711-30730. [CrossRef] [PubMed]

47. Parashar, A.; Paliwal, R.; Rambabu, P. Utility of Fuzzy Cross-Impact Simulation in Environmental Assessment. Environ. Impact Assess. Rev. 1997, 17, 427-447. [CrossRef]

48. Park, S.; Jeon, S.; Kim, S.; Choi, C. Prediction and Comparison of Urban Growth by Land Suitability Index Mapping Using GIS and RS in South Korea. Landsc. Urban. Plan. 2011, 99, 104-114. [CrossRef]

49. Parry, J.A.; Ganaie, S.A.; Sultan Bhat, M. GIS Based Land Suitability Analysis Using AHP Model for Urban Services Planning in Srinagar and Jammu Urban Centers of J.\&K., India. J. Urban. Manag. 2018, 7, 46-56. [CrossRef]

50. Romeijn, H.; Faggian, R.; Diogo, V.; Sposito, V. Evaluation of Deterministic and Complex Analytical Hierarchy Process Methods for Agricultural Land Suitability Analysis in a Changing Climate. ISPRS Int. J. Geo-Inf. 2016, 5, 99. [CrossRef]

51. Samarakoon, M.; Rowan, J.S. A Critical Review of Environmental Impact Statements in Sri Lanka With Particular Reference to Ecological Impact Assessment. Environ. Manag. 2008, 41, 441-460. [CrossRef] [PubMed]

52. Snell, T.; Cowell, R. Scoping in Environmental Impact Assessment: Balancing Precaution and Efficiency? Environ. Impact Assess. Rev. 2006, 26, 359-376. [CrossRef]

53. Svokos, A. Two Dead, at Least 4 Injured after Explosion at Virginia Gas Station. Available online: https://abcnews.go.com/US/ explosion-virginia-gas-station-sends-hospital/story?id=62964980 (accessed on 1 June 2021).

54. Tah, D.S. GIS-Based Locational Analysis of Petrol Filling Stations in Kaduna Metropolis. Sci. World J. 2017, 12, 8-13. [CrossRef] 
55. Talpur, M.A.H.; Napiah, M.; Chandio, I.A.; Khahro, S.H. Research Framework Focusing Transportation Accessibility Planning, Computer Based Modeling and Transportation Policy Outlines for Remote Regions of Developing World. Res. J. Environ. Earth Sci. 2013, 5, 32-40. [CrossRef]

56. Tuzmen, S.; Sipahi, S. A Multi-Criteria Factor Evaluation Model for Gas Station Site Selection. J. Glob. Manag. 2011, 2, 12-21.

57. Memon, Z.A.; Khahro, S.H.; Memon, N.A.; Ali, T.H. Improving Material Waste Management Performance: An Attribute Study for Provential Projects. Int. J. Civil. Eng. Technol. 2016, 7, 498-506.

58. Mundjulu, I. “Environmental Scoping Report (ESR) for a Fuel Storage Facility,” Tortoise Environmental Consultants, October. 2020. Available online: http://the-eis.com/elibrary/sites/default/files/downloads/literature/1941_ESR_Construction\%20 and \%20operation\%20of\%20a\%20Diesel\%20Depot\%20on\%20Erf\%20163_Lafrenz_Windhoek.pdf (accessed on 1 June 2021). 